YEARBOOK

of ANTITRUST

and REGULATORY

STUDIES

www.yars.wz.uw.edu.pl
Peer-reviewed scientific periodical, focusing on legal and economic issues of antitrust and regulation. Creative Commons Attribution-No Derivative Works 3.0 Poland License.

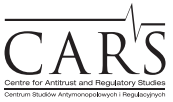

Centre for Antitrust and Regulatory Studies, University of Warsaw, Faculty of Management www.cars.wZ.uw.edu.pl

\title{
Addressing Anticompetitive Data Aggregation: a Comment to Bundeskartellamt Decision B6-22/16
}

by

Laura Skopowska*

\section{CONTENTS}

I. Introduction

II. Bundeskartellamt decision B6-22/16 - summary

1. Assessment of Facebook's dominant position

1.1. Facebook as a network

1.2. Facebook as a multi-sided market

1.3. Facebook's access to relevant data

1.4. Facebook's encounter with innovation-driven competitive pressure

2. Exploitative abuse of market power

2.1. Unlawfulness of data aggregation

2.2. Imbalance of power between Facebook and its users

3. Exclusionary abuse of market power

4. Prohibition

III. Bundeskartellamt decision B6-22/16 - analysis

1. Data aggregation as a barrier to market entry

2. GDPR violation as an antitrust violation

2.1. Bundeskartellamt's position

2.2. Commission and CJEU position

2.3. The delineation of competence between competition and data protection authorities

IV. Conclusion

* Laura Skopowska, LL.M, PhD candidate, Chair of European Law, Institute of Legal Studies, Polish Academy of Sciences; e-mail: laura.skopo@gmail.com. Article received: 8 July 2019, accepted: 12 September 2019. 


\section{Abstract}

Data aggregation, understood as the process of gathering and combining data in order to prepare datasets that might be useful for specific business or other purposes, is not per se forbidden. However, some forms of it can be considered anticompetitive. In the Decision B6-22/16 of the German Federal Cartel Office (Bundeskartellamt) data aggregation, which included the collection of data from sources outside of Facebook's social network (from Facebook-owned services such as WhatsApp and Instagram and from third party websites or mobile applications) and their combination with the information connected with a particular Facebook user account without that user's consent, constituted an abuse of Facebook's dominant position on the German market for social networks. The Bundeskartellamt found that the processing of user's personal data by Facebook has, to some extent, been carried out in a way which infringed GDPR provisions.

In the same decision, the Bundeskartellamt also identified the exclusionary nature of Facebook's anticompetitive behaviour. According to the Bundeskartellamt, the illegal data aggregation formed a barrier to entry for Facebook's competitors which, through compliance with data protection standards, found themselves in a worst position. Facebook, through its inappropriate data aggregation gained a competitive advantage.

The Bundeskartellamt's decision is, therefore, reflecting the anticompetitive dangers that data aggregation might pose. Nevertheless, it is debated whether the Bundeskartellamt, as a competition authority, is competent to determine the compliance or lack of compliance of business terms with the provisions of the GDPR. This paper analyzes the Bundeskartellamt's decision as to where an anticompetitive nature of data processing has been identified, and tries to answer the question why it is problematic that it was the Bundeskartellamt and not a data protection supervisory authority that has issued such a decision.

\section{Résumé}

Lagrégation de données, entendue comme le processus de collecte et de combinaison de données en vue de la préparation d'ensembles de données qui pourraient être utiles à des fins commerciales spécifiques ou pour d'autres fins, n'est pas en soi interdite. Toutefois, certaines formes peuvent être considérées comme anticoncurrentielles. Dans la décision B6-22/16, l'Office fédéral allemand des cartels (Bundeskartellamt) a examiné l'agrégation de données effectuée par Facebook, qui comprenait la collecte de données provenant de sources autres que le réseau social Facebook (de services appartenant à Facebook tels que WhatsApp et Instagram ou sites Web tiers ou applications mobiles) et leur combinaison aux informations liées aux comptes utilisateurs Facebook sans consentement de l'utilisateur. Premièrement, le Bundeskartellamt a considéré qu'un tel comportement constituait un abus de position dominante de Facebook sur le marché allemand des réseaux 
sociaux. Le Bundeskartellamt a également constaté que le traitement des données à caractère personnel des utilisateurs par Facebook a, dans une certaine mesure, été effectué en violation des dispositions du GDPR. Dans la même décision, le Bundeskartellamt a aussi identifié le caractère exclusif du comportement anticoncurrentiel de Facebook. Selon le Bundeskartellamt, l'agrégation illégale de données a constitué une barrière à l'entrée pour les concurrents de Facebook qui, en respectant les normes de protection des données, se sont trouvés dans la pire position. Facebook, par son agrégation inappropriée de données, a acquis un avantage concurrentiel. La décision du Bundeskartellamt reflète donc les dangers anticoncurrentiels que l'agrégation de données pourrait poser. Néanmoins, la question de savoir si le Bundeskartellamt, en tant qu'autorité de concurrence, est compétent pour déterminer si les conditions commerciales sont conformes ou non aux dispositions du GDPR est une question qui fait débat. Le présent article analyse la décision du Bundeskartellamt lorsqu'une nature anticoncurrentielle du traitement des données a été identifiée et essaye de répondre à la question du fait que ce soit le Bundeskartellamt qui ait pris une telle décision et non une autorité de contrôle en charge la protection des données.

JEL: K21, L40

Key words: data aggregation; data-driven markets; platforms; networks; data; information asset; abuse of dominant position; abusive business terms; exclusionary abuse; exploitative abuse.

\section{Introduction}

Data aggregation, for the purpose of this paper, should be understood as the process of gathering and combining data in order to prepare datasets that might be useful for specific business or other purposes. Although data aggregation is not per se forbidden, some forms of it can be considered anticompetitive. In the Decision B6-22/16 ${ }^{1}$ of the German Federal Cartel Office (hereinafter: Bundeskartellamt or the Office) data aggregation, which included the collection of data from sources outside of Facebook's social network (from Facebook-owned services such as WhatsApp and Instagram and from third party websites or mobile applications) and their combination with information connected with a particular Facebook user account without

1 Bundeskartellamt Decision B-6/22/16 dated from 6 February 2019, p. 67. Retrieved from: https://www.bundeskartellamt.de/SharedDocs/Entscheidung/DE/Entscheidungen/Missbrauchsaufsicht/2019/B6-22-16.pdf;jsessionid=FC6BF3FCDCB8F64ECB7D934E0CA65021.1_cid387? blob $=$ publicationFile $\& v=8$ (2 (hereinafter: Decision). 
that user's consent, constituted an abuse of Facebook's dominant position on the German market for social networks.

The decision pointed out the twofold nature of the abuse. Firstly, there exists exploitation of users who indeed accepted Facebook's terms and conditions (within which privacy and cookie's policy were embedded) that allowed Facebook to combine Facebook account data together with data gathered outside the social network service, but in the view of the data protection standards, their acceptance cannot be viewed as a valid consent, which would be an appropriate legal basis for such a wide scope of processing activities. This acceptance was conditional on the possibility to provide Facebook's social network service to users, whereas such a great scope of data processing activities was not necessary for the provision of the social network service, and should be regarded as forced. Looking at Facebook's dominant position in the national market of social network services, and the direct as well as indirect network effects that are natural for such a multi-sided advertising-funded market, and the resulting imbalance of powers between users and the social network provider, the Bundeskartellamt concluded that the terms of use of the service, which require the user to accept the processing of wider scope of data than is necessary from the General Data Protection Regulation's ${ }^{2}$ (hereinafter: GDPR) perspective, constitutes abusive business terms. ${ }^{3}$

Secondly, the Bundeskartellamt identified the exclusionary nature of Facebook's anticompetitive behaviour. According to the Office, illegal data aggregation formed a barrier to entry for Facebook's competitors which, through compliance with data protection standards, found themselves in a worst position than Facebook, which gained a competitive advantage by inappropriate data aggregation from different sources.

The Bundeskartellamt's decision is reflecting the real and potential anticompetitive dangers that data aggregation might pose. Nevertheless, it is debated whether the Bundeskartellamt, as a competition authority, is competent to determine the compliance or lack of compliance of business terms with the provisions of the GDPR.

2 Regulation (EU) 2016/679 of the European Parliament and of the Council of 27 April 2016 on the protection of natural persons with regard to the processing of personal data and on the free movement of such data, and repealing Directive 95/46/EC (General Data Protection Regulation), OJ L 119, 4.5.2016, p. 1-88.

3 In the Bundeskartellamt's view finding of exploitative abuse can be based on the fact that also a breach of a rule from outside competition law took place. See: Volmar and Helmdach, 2018, p. 198. 


\section{Bundeskartellamt decision B6-22/16 - summary}

\section{Assessment of Facebook's dominant position}

According to the Bundeskartellamt, Facebook is the dominant company in the German market for social networks for private users (Bundeskartellamt, 2019 , p. 3). Other social networks or services which were only partially substitutable to Facebook's social network (such as: Pintrest, LinkedIn, Twitter) were excluded from the relevant market definition, and the decision that Facebook is a dominant company on the relevant market is explained by the fact that Facebook's user-based market share among daily active users in Germany exceeded $95 \% .^{4}$

The market shares where not, however, the sole indicator of Facebook's market power. The introduction of $\S 18$ paragraph 3 a to the $\mathrm{GWB}^{5}$, required the Bundeskartellamt, in the case of multi-sided markets and networks such as Facebook, to also asses additional conditions such as: direct and indirect network effects, the parallel use of services from different providers and the switching costs for users, the undertaking's economies of scale arising in connection with network effects, the undertaking's access to data relevant for competition and finally innovation-driven competitive pressure, while analyzing the dominant position of entities present on the relevant market. ${ }^{6}$

\subsection{Facebook as a network}

$\S 18$ paragraph 3a GWB distinguishes multi-sided markets and networks from traditional markets and establishes several other conditions that should be taken into consideration while assessing the existence of a dominant position of the entity. The Facebook social network service fulfils the definition of a network presented in the Gesetzentwurf der Bundesregierung: Entwurf eines Neunten Gesetzes zur Änderung des Gesetzes gegen Wettbewerbsbeschränkungen ${ }^{7}$ (An

4 The Bundeskartellamnt considers the number of daily active users as the key indicator and relevant measure for assessing the network's competitive significance and market success, as a social network's success is measured by the intensity of use (Bundeskartellamt, 2019, p. 6).

5 Act against Restraints of Competition in the version published on 26 June 2013 (Bundesgesetzblatt (Federal Law Gazette) I, 2013, p. 1750, 3245), as last amended by Article 1 of the law of 1 June 2017 (Federal Law Gazette I, p. 1416). Retrieved from http://www.gesetzeim-internet.de/englisch_gwb/englisch_gwb.html\#p0057 (hereinafter: GWB).

6 See: $\$ 18$ para. 3a GWB.

7 Drucksache 18/10207 - Deutsher Bundestag - 18. Wahlperiode, Retrieved from: http:// dipbt.bundestag.de/dip21/btd/18/102/1810207.pdf (last accessed: 15.06.2019), (hereinafter: Proposal). 
Official Proposal of a Ninth Amendment to the Law against Restrictions on Competition; hereinafter: the Proposal) where it is stipulated that a product has network character when direct network effects exist between the users of the product. ${ }^{8}$ Such direct network effects exist when the growth or decline in the number of users has an immediate positive or negative impact on the usefulness of the product or its performance for the individual user. ${ }^{9}$

The Bundeskartellamt identified that the more private users are active on Facebook's social network, the higher the benefit for these users, as the interaction possibilities between users, and their ability to find friends and acquaintances, increases with more users of the social network. ${ }^{10}$ Therefore direct network effects could be seen in the fact that the attractiveness of a social network increases with an increasing number of other users, as it improves users' possibility to be able to communicate with exactly those persons they are looking for. ${ }^{11}$ Facebook's dominant market position is not solely funded on the amount of its social network users, but particularly on the identity of these users, which should be known for a potential user. ${ }^{12}$ These are so called 'identity-based' network effects. ${ }^{13}$ It is, therefore, difficult to motivate users to switch to another social network as strong identity-based network effects exist, and Facebook is the only social network provider which proposes a sufficiently big, and useful ${ }^{14}$ from the users' perspective, social network (Bundeskartellamt, 2019, p. 6 and 2019a, p. 4). Especially when the possibility to switch from Facebook to other social network providers is weakening as Facebook's competitors tend to exit the market (Bundeskartellamt, 2019, p. 6), and there is a visible lock-in effect that keeps users within the network. The direct network effects associated with the functioning of Facebook's social network fulfils the GBW's definition of the 'network'.

\subsection{Facebook as a multi-sided market}

In multi-sided markets at least two distinguishable customer groups come together. ${ }^{15}$ An example of such a market can be a platform that acts as an

8 Proposal, p. 48.

9 Ibidem.

10 Decision, p. 67.

11 See: Decision, p. 67. See also: Bundeskartellamt (2019a), p. 4.

12 Decision, p. 67.

13 Ibidem.

14 Useful, in this context, means, the user pool is relevant for the user, as he/she will be able to identify his/her friends among the users. According to the results of the survey carried by the Bundeskartellamt during the proceedings, about $85 \%$ of the users surveyed consider it as least important that their friends also use the network (See: Decision, p. 85, point 274)

15 Proposal, p. 49. 
intermediary and brings at least two customer groups together. Members of one customer group benefit from the presence on the platform of another customer group. The platform as an intermediary creates a value that these customers could not readily obtain without coordination provided by the platform (Evans and Schmalensee, 2007, p. 2). Multi-sided markets may exist in many forms. One of them is a shopping mall where the identified 'customer groups' are, on one side - stores and on the other - customers. Another multi-sided markets are ad-supported media where the customer groups consist of advertisers and consumers who listen to the radio, watch TV or read newspapers and buy products or services advertised through these media. More examples include operating systems market (developer of programmes and end customers of the operating system), game consoles market (developers of games and players), market of credit card systems (credit card accepting businesses and credit card owners), app stores (developers of apps and endusers) ${ }^{16}$. In order for a platform to fulfil the concept of a multi-sided market of $\S 18$ paragraph $3 \mathrm{a}$ GWB, the intermediary role of the market should exist. In the case of Facebook's social network, which is financed through targeted advertising, Facebook acts as an intermediary between private users and advertisers. ${ }^{17}$

Other characteristics of multi-sided markets include, in particular, indirect network effects. ${ }^{18}$ They arise from the fact that several, distinguishable demand groups use the network. ${ }^{19}$ Indirect network effects exist when the benefit or gain of one customer group depends on the number of the other customer group within the platform. ${ }^{20}$ From the perspective of Facebook's social network, the benefits of the fact that the network has a greater amount of users lies on the side of advertisers. ${ }^{21}$ The greater the number of users, the more users see the advertisements and the sale opportunities for advertised products rise. ${ }^{22}$ Although as a rule, each group benefits from the fact that the other group uses the platform, a user survey performed during the proceedings revealed that the vast majority of the surveyed users find targeted advertising negative or at least neutral. ${ }^{23}$ Facebook's primary product - the social network - shares the characteristics of a multi-sided market and a network in accordance with

16 The Proposal, pp. 48-49. For further examples and information about multi-sided markets please see: Evans and Schmalensee, 2007, pp. 6-11.

17 Decision, p. 67

18 Proposal, p. 49.

19 Proposal, p. 50

${ }^{20}$ Decision, p. 68. See also: Bundeskartellamt, 2018, p. 9.

${ }^{21}$ Decision, p. 68

22 Ibidem.

${ }^{23}$ Decision, p. 68, point 221. 
$\S 18$ paragraph $3 \mathrm{~A}$ GWB, the dominant position of Facebook on the social network market has been further analyzed taking into account:

1. direct and indirect network effects,

2. parallel use of services from different providers and switching cost for users,

3. economies of scale arising in connection with network effects,

4. access to data relevant for competition,

5. innovation-driven competitive pressure.

Since this paper's aim is to focus on the possible anticompetitive effects of data aggregation carried out by Facebook, further analysis will be limited to the criteria concerning access to relevant data and innovation-driven competitive pressure.

\subsection{Facebook's access to relevant data}

The purpose of introducing the criterion of 'undertakings' access to data relevant for competition' to the GWB assessment of market dominance indicates that the German legislator sees the possibility for a market position of a company to be significantly influenced by its access to data, especially when the company offers a data-driven product such as an advertising-financed social network. ${ }^{24}$ Market power is, therefore, not necessarily associated with pricing but it can also be associated with (exclusive) access to data. ${ }^{25}$ The express inclusion of the new feature in the catalogue of $\S 18 \mathrm{GWB}$ has as its purpose the improvement of the analysis of market and competitive conditions and the examination of whether there is market dominance, especially when challenges arise of applying competition law in the digital age. ${ }^{26}$ This criterion takes into account the fact that competitive advantages of companies with Internet-based business models can be based on special resources and capabilitie. ${ }^{27}$ The market position might, therefore, depend on the type and extent of data and their importance for the business activity. ${ }^{28}$

Exclusive control over certain competitive data can be a barrier to entry for competitors, especially if there are indirect network effects on the market and there exist limited opportunities for competitors to build comparably large datasets. ${ }^{29}$ However, the mere possession of a great amount of data does not mean the company will definitively achieve a dominant market position, as the

\footnotetext{
24 See: Proposal, p. 51.

25 Proposal, p. 48.

26 Ibidem.

27 Proposal, p. 48.

28 Proposal, p. 51.

29 Ibidem.
} 
ability to aggregate data through their analysis and combination with other data is also relevant for the creation of possible competitive advantages. ${ }^{30}$

The Bundeskartellamt, in its decision, agreed that the extent of data processing can also be considered as a part of the quality of the service, because the economic use of customer and user data as well as data of third parties is - especially in digital markets - a competitively significant factor. ${ }^{31}$ The advertisers who finance the network are also interested in as detailed datasets about their potential customers as possible. There, therefore, exist a strong incentive to widen the scope of data processed by the platform, as the market success of the service is related to a strongly-detailed user profile. ${ }^{32}$ Access to competitive data is a significant aspect of examination of market power of social networks, because of the characteristics of this product, which is a data-driven advertising-funded product, whose affordability is linked to the aggregated personal data of users. ${ }^{33}$ Even Facebook agreed that the accuracy and degree of personalization of a social network is dependent on the number and variety of received data - the broader the database, the more effective the service that can be provided. ${ }^{34}$

Facebook collects data from a number of different sources. Firstly, Facebook gathers data about its users while they are involved in customary and purposeful use of its social network. ${ }^{35}$ At registration, the user normally provides Facebook with data about its e-mail address, name and surname and age. ${ }^{36}$ Through the establishment of a Facebook profile page, the user can also share information about its gender, relationship status, place of residence, education, occupation, employer, interests and hobbies. ${ }^{37}$ An active user also gives Facebook access to his posts and interactions with other Facebook users. ${ }^{38}$ Through the existing mobile location function and other technical possibilities involving the geographical mapping of IP addresses, Facebook accesses information about users movements and paths he travels. ${ }^{39}$ When a user logs-in he can be recognized by Facebook across devices and device-related information is also gathered. ${ }^{40}$ Facebook accesses additional

\footnotetext{
30 Proposal, p. 51.

31 Decision, p. 120, point 380.

32 Decision, p. 120, point 381.

33 Decision, p. 154, point 482.

34 See Decision, p. 158, point 493.

35 Decision, p 154, point 483.

36 Ibidem.

37 Ibidem.

38 Decision, p 154-155, point 484.

39 Ibidem.

40 Ibidem.
} 
information about the identity of user's friends, who might not be a part of Facebook, from the address books that the user uploads to Facebook. ${ }^{41}$

Secondly, Facebook gathers information collected through its corporate services such as WhatsApp, Instagram, Oculus etc.

The third source of data is found in third-parties who use Facebook developer interfaces (API) on their websites or in their mobile applications. Such social plug-ins as 'Share' or 'Like' buttons and 'Facebook Login' 42 act as tracking cookies which monitor behaviour of users on these 'connected' websites or apps, even if the user is not registered or logged into Facebook. ${ }^{43}$ Also Facebook's measurement and analysis tools used by third-party companies, in order to assess the success of their websites or mobile apps, serve as an important source of data. ${ }^{44} \mathrm{~A}$ user who is visiting the website of a third-party is monitored and information about his IP address, browser type, URLs of visited websites, time of a visit, etc. is sent to Facebook thorough ID integrated in the cookie that enables the user behaviour to be combined with the user's Facebook profile information. ${ }^{45}$ When a mobile application is used then the information about the user's Facebook app ID, and metadata about the operating system used (its name, version) and about the app installed, is sent to Facebook through an advertising ID of the operating system, thus the use of additional cookie is redundant. ${ }^{46}$

The fourth source of data are the advertisers ${ }^{47}$ who, while ordering an advertising campaign to be launched on Facebook's social network, have a possibility to upload their own customers list which includes data already possessed by the advertisers on their existing customers. ${ }^{48}$ Customer data might include their last name, profession, address, city, country, date of birth, age, gender, buying behaviour and various other information which is then matched with Facebook data. These data help Facebook to identify the target audiences for particular products. ${ }^{49}$

Access to such data allows constant adaptation of products through technical improvements. ${ }^{50}$ The vast data sources secure the constant funding of the

41 Ibidem.

${ }^{42}$ With the 'Facebook Login', the user can access the third party website with his Facebook identifying registration data, i.a. with his e-mail address/ phone number and his Facebook password. (Decision, p. 22, point 63).

43 Decision, p. 155, point 486.

44 Ibidem.

45 Ibidem.

46 Ibidem.

47 Decision, p. 156, point 487.

48 Ibidem.

49 Ibidem.

50 See Decision, p. 156, point 488. 
network through advertising, as the data allow for refining of the algorithms that assign advertisements to the particular user. ${ }^{51}$ The personalized content that is visible on Facebook user profile's News Feed can easily be adapted and modified in accordance with the information resulting from the array of data collected. ${ }^{52}$ The aggregated data help to improve algorithms that calculate relevance of posts for a particular social network user. ${ }^{53}$ Moreover, the diverse data sources allow for highly accurate advertising targeting, the increased data sources allow for a prompt and accurate identification of target groups according to specific personal criteria. ${ }^{54}$ Data can be also further used for product development and innovation research..$^{55}$ The optimization of the News Feed algorithm and other Facebook products attracts new users and the improved targeting capabilities attract advertisers that in turn bring their own data sources and generate further data through the use of Facebook measurement tools. ${ }^{56}$ This various sources of data which are combined with Facebook's social network user profiles allows Facebook to create highlydetailed user profiles that might be difficult or even impossible to duplicate by Facebook's competitors. ${ }^{57}$

Most competitors - with the exception of Goggle - do not have access to a comparable extent of detail-like level of personal data.$^{58}$ Facebook's base of 23 million daily active users allowed Facebook to accumulate huge amounts of data. ${ }^{59}$ By taking into account that data usability and value is determined by their combination to certain patterns, the combination increases the value of data which is augmented if other data elements are available. ${ }^{60}$ By means of algorithms, the on-line behaviour and interests of users can be predicted and with rising amount of user-related and other data available, the prediction can be made even more accurate. ${ }^{61}$ The Bundeskartellamt concluded that larger amounts of available data retrieved from various sources imply the rise of a market advantage. ${ }^{62}$

Since Facebook has a large number of different data sources that help it to aggregate data which are of competitive relevance for the provision of

51 Ibidem.

52 Decision, p. 156, point 489.

53 Ibidem.

54 Decision, p. 157, point 492.

55 Decision, p. 158, point 493.

56 Decision, p. 159, points 496- 497.

57 See Decision, p. 158-159, point 495 and p. 160, point 498.

58 Decision, p. 154 , point 482.

59 Decision, p. 159, point 495.

60 Ibidem.

61 Ibidem.

62 Ibidem. 
a social network, an additional market barrier has been identified. ${ }^{63}$ Although possibilities exist for competitors to install cookies and purchase third-party data, the characteristics of Facebook's accurate and highly-detailed data show that the competitors' sources are not comparable. ${ }^{64}$ Competitors cannot duplicate the data collection accessible to Facebook, especially when they are smaller competitors who only have limited financial or business options to aggregate data from various relevant sources. ${ }^{65}$ Media agencies reaffirmed that Facebook has advertising-relevant data that is not provided by any other online advertising provider, that Facebook has more detailed data than other providers, and that Facebook has more data than other publishers. ${ }^{66}$ Thus, the investigation showed that Facebook has a unique database. ${ }^{67}$ Even if the data collection of Google Group is comparable to the data aggregated by Facebook in the view of its amount and detail, Google's database did not achieve market success in the social networks for private users market, which only shows the strong direct network effects that are associated with Facebook's social network service. ${ }^{68}$ Facebook has therefore advantageous or even exclusive access to data sources which are of competitive relevance.

\subsection{Facebook's encounter with innovation-driven competitive pressure}

According to $\S 18$ paragraph 3a point $5 \mathrm{GWB}$, in assessing the market position of an undertaking, account shall also be taken to innovation-driven competitive pressure. This criterion has been introduced as reflecting the dynamic nature of digital markets, where one innovative product can be easily replaced by another innovative product, the so called 'theory of destructive creation'. ${ }^{69}$ The competitive pressure, due to the innovative power of Internetbased services, includes the possibilities of disruptive changes that can lead

63 See Decision, p. 154, point 482.

${ }^{64}$ Decision, p. 160, point 498. The investigation showed that Facebook's competitors, except Google, did not collect data from their corporate services, nor have they installed social plugins such as Like or Share or Log-in button (Decision, p. 160, point 498).

65 Decision, p. 160, point 498.

66 Decision, p. 160, point 499.

67 Ibidem.

68 Decision, p. 160-161, point 499.

69 Online platforms often engage in constant incremental innovation as they seek to obtain advantages over rivals to attract participants on multiple sides and are subject to episodic, but increasingly frequent, disruptive innovation in which new, or seemingly different, firms attract their customers away. This dynamic competition is particularly important for 'attention' platforms for which competition is designed to attract the attention of users, which is then resold to marketers, including advertisers, who want to persuade those users to buy things. An attention seeker is under constant threat that someone will come up with an entirely clever new way to grab people's attention (Evans, 2016, p. 3-4). 
to the vulnerability of a strong market position of a company in the short term. ${ }^{70}$ Each case should be therefore carefully examined as to whether there isn't a merelyabstract, too vague vulnerability of the market position. The possibility of eventual disappearance of a market-dominant position would lead to a denial of market dominance and the allegation of abuse of that position would per se be removed from scrutiny. ${ }^{71}$

Taking into account the disruptive nature of innovative markets, the Bundeskartellamt had also to assess the future market power of Facebook, taking into account the possible innovations that might pose a danger to its dominant position. The Office came to the conclusion that even an innovative power of the Internet will not have any negative impact on the market power of Facebook. ${ }^{72}$ The high market shares of Facebook and direct and indirect network effects indicate that Facebook's dominant market position is secured. ${ }^{73}$ None of the competitors had successfully build pressure on the market position of Facebook through innovation. ${ }^{74}$ Moreover, it has been identified that Facebook-owned innovations show that there is no competitive pressure on the market position on Facebook as Facebook successfully transformed from a 'web company' to a 'mobile first company' through the introduction of new technological possibilities to users and advertisers. ${ }^{75}$ Furthermore, the Bundeskartellamt investigation showed that the only existing innovationdriven competitive pressure to Facebook is centred on sub-functions of social networks (such as Instagram, Facebook Messenger, WhatsApp, Poke, Paper, Moments or Facebook Camera) as standalone apps and not to the Facebook social network as a whole. ${ }^{76}$ This substitutional competition remains, however, marginal and the market position of Facebook is not endangered. ${ }^{77}$ All the above shows little vulnerability of Facebook's future market position on the social network market for private users to innovative-driven competitive pressure. $^{78}$

70 Proposal, p. 51.

71 Ibidem.

72 Decision p. 161, point 501.

73 See Decision, p. 161, points 502-503.

74 Decision, p. 161, point 504.

75 Decision, p. 163, point 506; For the list of innovative Facebook own products and their description please see: Decision, p. 163-164, points: 507-511.

76 Decision, p. 165, point 514.

77 Ibidem.

78 Ibidem. 


\section{Exploitative abuse of market power}

The Bundeskartellamt, after taking into account all of the $\S 18$ paragraph 3a GWB conditions, concluded that Facebook is a dominant company on the national market for social networks for private users. The Office has also identified that Facebook has abused its dominant position in an exploitative and exclusionary way. ${ }^{79}$

The exploitative abuse presented itself through Facebook's infringement of the GDPR. The Bundeskartellamt concluded that the market power of Facebook enables data processing even against the will of the users, and thus to a much greater extent than users might have expected. ${ }^{80}$ At the moment of setting up a Facebook user account, one has to accept Facebook's terms of service. These terms include references to the data and cookie policies where it is stipulated that Facebook also collects data on users and their devices from its corporate services, as well as, outside of Facebook-related activities via Facebook analytical and measurement tools implemented in third party mobile applications or websites. Without the acceptance of these terms and conditions, the Facebook social network service would not be provided.

\subsection{Unlawfulness of Facebook's data aggregation}

Each personal data processing activity that concerns users residing in the European Economic Area has to satisfy one of the legal bases indicated by the GDPR. Articles 6 and 9 of the GDPR provide a list of the legal grounds that might be invoked by any entity which is carrying out the processing activity for this activity to be legal. For the processing of personal data, which are not a 'special category' data, one of the following grounds has to be established:

- the data subject consents to the processing of his or her personal data for one or more specific purposes; (Art. 6. 1a)

- the necessity of processing to perform a contract to which the data subject is party or in order to take steps at the request of the data subject prior to entering into a contract; (Art. 6. 1b)

- the necessity of processing for compliance with a legal obligation to which the controller is subject; (Art. 6. 1c)

- the necessity of processing to protect the vital interests of the data subject or of another natural person; (Art. 6.1d)

79 'Abuses can be exploitative, earning an unjustifiably high profit at the expense of customers, or exclusionary, aimed at excluding competitors from the market by other means than competitive efficiency (e.g. by refusing to supply competitors with necessary input on upstream markets or by unjustifiably lowering prices)' (Zanfir-Fortuna, and Ianc, 2018, p. 5).

80 See Decision p. 120, point 385. 
- the necessity of processing for the performance of a task carried out in the public interest or in the exercise of official authority vested in the controller; (Art. 6. 1e)

- the necessity of processing for the purposes of the legitimate interests pursued by the controller or by a third party, except where such interests are overridden by the interests or fundamental rights and freedoms of the data subject which require protection of personal data, in particular where the data subject is a child. (Art. 6. 1f)

With regard to the personal data processing activity carried out by Facebook, the legal grounds identified by Facebook were the necessity to perform a contract (Art. 6.1.b GDPR) and the necessity to fulfil legitimate interests pursued by Facebook (6.1.f GDPR) (Bundeskartellamt, 2019, p. 3). These grounds where, however, identified as insufficient, from the Office's perspective. The Bundeskartellamt indicated that the fulfilment of the contract did not necessitate the processing of such a vast array of personal data that has been determined in Facebook's terms and conditions (Bundeskartellamt, 2019, p. 10).

Nor did the second proposed ground pass the scrutiny of the Bundeskartellamt. The Office did not recognize any particular interest of Facebook, third parties and users that could outweigh the interests or fundamental rights and freedoms of the data subject. The Office concluded that the only valid ground for such a far-reaching data processing is a voluntary consent, which has not been given by users to Facebook. The mere fact of accepting terms and conditions in order to conclude the contract with Facebook and set up a Facebook account, cannot be regarded as an act of providing the valid consent for personal data processing, which was described under the cookie and privacy policy in Facebook's terms and conditions. ${ }^{81}$

Moreover, the Office acknowledged that consent cannot be regarded as valid when it is the prerequisite for using the social network service (Bundeskartellamt, 2019, p.10). ${ }^{82}$ Article 4(11) GDPR stipulates that consent of the data subject means 'any freely given, specific, informed and unambiguous indication of the data subject's wishes by which he or she, by a statement or by a clear affirmative action, signifies agreement to the processing of

81 'Compulsion to agree with the use of personal data additional to what is strictly necessary limits data subject's choices and stands in the way of free consent. As data protection law is aiming at the protection of fundamental rights, an individual's control over their personal data is essential and there is a strong presumption that consent to the processing of personal data that is unnecessary, cannot be seen as a mandatory consideration in exchange for the performance of a contract or the provision of a service' (Article 29 Working Party Guidelines on consent under Regulation 2016/679, 2018, p. 8).

82 Summary, p. 11. 
personal data relating to him or her'. Article 4(11) GDPR is substantiated with recitals 42 and 43 of the GDPR which provide that '[c]onsent should not be regarded as freely given if the data subject has no genuine or free choice or is unable to refuse or withdraw consent without detriment' 83 and that 'if the performance of a contract, including the provision of a service, is dependent on the consent despite such consent not being necessary for such performance' ${ }^{\prime}{ }^{4}$ Thus, the consent for particular processing cannot be regarded as freely given when it is bundled with the acceptance of terms or conditions, nor when the performance of the contract or service is tied with the request for consent to process personal data, which are not necessary for the performance of that contract or service. The mere acceptance of Facebook's terms and conditions by users does not fulfil the requirement of a freely given consent for the data processing indicated under Facebook's terms and conditions, which are not necessary to perform a contract and provide a social networking service. The Bundeskartellamt indicated that 'a personalized network could also be based to a large extent on user data processed in the context of operating the social network' 85 , thus 'processing data from third-party sources to the extent determined by Facebook in its terms and conditions is neither required for offering the social network as such nor for monetizing the network through personalized advertising, ${ }^{86}$ It can be concluded that Facebook has processed data without a legal basis, which means that data aggregated that were not necessary to provide a social network service have been processed unlawfully.

\subsection{Imbalance of power between Facebook and its users}

Taking into consideration the unlawful nature of data aggregation and the imbalance of the bargaining position between Facebook and the users of its dominant social network, the Bundeskartellamt found that the terms and conditions imposed by Facebook could be identified as constituting an exploitative abuse. ${ }^{87}$ The Office invoked the relevant Federal Court's of Justice jurisprudence, which shows the conditions under which $\S 19$ GWB can be applied. According to the Bundeskartellamt's interpretation of the $V B L-G e g e n w e r t I^{88}$ and Pechstein ${ }^{89}$ rulings, the mere fact that the dominant

83 Recital 42 GDPR.

84 Recital 43 GDPR.

85 Summary, p. 10.

86 Ibidem.

87 Decision, p. 169, point 523.

88 Federal Court of Justice, judgment of 6 November 2013, file KZR 58/11, VBL Gegenwert I.

${ }^{89}$ Federal Court of Justice, judgment of 7 June 2016, file KZR 6/15, Pechstein v International Skating Union. 
company infringes provisions of law which binds it, also when this law applies to its data processing activities, demonstrates that an abuse of dominance took place. There is therefore no need to carry out a balance of interest test in the case where a norm's addressee violates the rules of the legal system. ${ }^{90}$ Nevertheless, the Bundeskartellamt carried this test out as a 'precautionary measure ${ }^{91}$ where it has taken similar factors into consideration as those analyzed under the GDPR-compliance test.

As already presented, Facebook apart from its social network and useroriented services and products (such as: Instagram, WhatsApp, Masquerade, Oculus) offers a range of different services and tools for website operators, developers, advertisers and other businesses. These tools, called 'Facebook Business Tools', allow to integrate social plug-ins such as: 'Like' and 'Share' buttons, Facebook login and other analytics services into websites and products offered by those third parties. Where visible interfaces such as 'Like' or 'Share' buttons are embedded on websites and mobile applications, then the data about a user's behaviour that entered the website or installed an app, will be sent directly to Facebook. ${ }^{92}$ This transfer of data will start even if the user will not scroll over the website or click on the Facebook button. ${ }^{93}$ Moreover, invisible analytics tools which are embedded on the website for user analyses, carried out by the website operator, also transfer user data to Facebook every time a user enters the website. ${ }^{94}$ Furthermore, accordingly to Facebook terms and conditions, these data can be combined with data from a user Facebook account and used by Facebook even if the user blocked web tracking in its browser or device settings. ${ }^{95}$ The integration of Facebook Business Tools allows Facebook to also track user behaviour on these websites even if they are not logged into or registered with Facebook. ${ }^{96}$ The analytics tools available to third party businesses represent an important data source for Facebook as they provide substantial information on the devices used and on the interactions of users with the website to Facebook. Facebook then through ID integrated in a form of a cookie, substantiated with information stored on the device, assigns these data to the user account on Facebook. ${ }^{97}$

Taking into consideration all of the above, the Bundeskartellamt found that the terms and conditions imposed by Facebook could be identified as

90 Decision, p. 281, point 893.

91 Decision, p. 281, point 894.

92 Press release, p. 3.

93 Ibidem.

94 Ibidem.

95 FAQ p. 1.

96 FAQ p. 3.

97 FAQ p. 3. 
constituting an exploitative abuse, ${ }^{98}$ because when one contractual party is so powerful that it is practically able to dictate the terms of the contract and the contractual autonomy of the other party is eliminated, the general clauses under civil law, which include also $§ 19$ GBW, should be applied in order to balance the conflicting positions of the contractual parties. ${ }^{99}$ Since data protection law can be considered a special law the aim of which is to reconcile interests between consumers ('data subjects') and entities which process their data for commercial purposes, ${ }^{100}$ the provisions of data protection law under the GDPR must be analyzed when assessing the appropriateness of data processing conditions of a dominant undertaking under competition law. ${ }^{101}$

The Bundeskartellamnt identified that data processing conditions embedded into terms of use of the social network, are to be considered a type of business terms under $\S 19$ paragraph 1 and paragraph 2 no. 2 GWB. ${ }^{102}$ The Office concluded that Facebook's social network's terms of use for an individual user, concretized by the data and cookie policies and other related documents, constitute an abuse of Facebook's dominant market position in the market for social networks for private users, since they violate the requirements of the GDPR. ${ }^{103}$ Facebook abused its dominant position by obtaining userand device-related data from different sources (such as Facebook corporate services: WhatsApp, Oculus, Masquerade and Instagram; and Facebook Business Tools) and combining them with the data of Facebook's social network user accounts, without users' consent. ${ }^{104}$

This practice led Facebook to have 'quasi' unlimited access to personal data of its users. ${ }^{105}$ Moreover, the Office carried the balance of interest test, which follows the requirements set up under the Perstein case and involved the weighing of affected fundamental rights ${ }^{106}$ of users and their right to informational self-determination, which led to the same conclusions as the GDPR compliance test.

98 Decision, p. 169, point 523.

99 Decision, p. 169-170, point 527.

100 Decision, p. 171, point 530.

101 Decision, p. 169, point 526;

102 D19 para. 1 together with para. 2 no. 2 GWB stipulates that an abuse of a dominant position of a dominant undertaking who as a supplier or purchaser of a certain type of goods or commercial services demands payment or other business terms which differ from those which would very likely arise if effective competition existed, is prohibited. See also: Decision, p. 168 , point 524 .

103 Decision, p. 169, point 523.

104 Decision, p. 168, point 522.

105 Decision, p. 283-284, point 902.

106 Decision, p. 282, point. 895. 
At the end, an isolated from German jurisprudence, competition law balance of interest has been proposed. Under this test, the Office tried to balance the reasonable expectations of users, understood as their interest in understanding the scope and meaning of terms, scale, aim and sources of the processing activities linked with the provision of the service, ${ }^{107}$ together with Facebook's interest in using data for the improvement of its products and personalized advertising. ${ }^{108}$ The Bundeskartellamnt recognized that the processing of data is necessary in the data-driven business model that Facebook represents, but it does not mean that the scope of the data processing can be unilaterally determined by the dominant entity. ${ }^{109}$ The scope of processing is, therefore, subject to antitrust review ${ }^{110}$ and it was found to be abusive since users did not have a possibility to make independent decisions as to the contract conditions ${ }^{111}$, nor did they have a possibility to prevent Facebook from collecting and processing unlimited data from the aforementioned variety of sources. ${ }^{112}$

The only possibility to limit the scope of data processing activities carried out by Facebook was for a user to switch to another social network, cease to use Facebook-related services or to practically stop using the Internet at all. ${ }^{113}$ Moreover, the Bundeskartellamt found that in case of Facebook social plug-ins (Like, Share buttons), Facebook Log-in function, measurement and analytics tools installed in third party websites, for a user to limit Facebook's access to data, he would have to practically stop using the Internet, as it would not be possible for him to discern websites which have this tools embedded from those which do not, as they can also be invisible. ${ }^{114}$ Since, Facebook enjoys a dominant position on the relevant market for social networks, it is not feasible to limit the 'unlimited' Facebook data gathering through switching to another social network. ${ }^{115}$ If users will not leave Facebook's social network, then the only possibility, meaning the global limitation of their Internet activity together with the refusal to use widely-used Facebook-related services (such as WhatsApp or Instagram), will constitute a significant and disproportionate restriction to users' willingness to generally use the Internet. ${ }^{116}$

107 Decision, p. 283, point 899.

108 Decision, p. 282-283, points 897, 899.

109 Decision, p. 282, point 897.

110 Ibidem.

111 Decision, p. 283, point 899.

112 Decision, p. 283-284, point. 902.

113 Decision, p. 284, points 902-903, 905.

114 Decision, p. 284-284, point 905.

115 Decision, p. 284, point. 902.

116 Decision, p. 284, point 903. 
The user, therefore, seems to have no possibility to limit Facebook's data aggregation that is made outside of the social network. He is, thus, forced to allow Facebook to assign his data gathered outside the social network to his Facebook user account even when he uses third-party websites or services. This constitutes an appropriate forcing of access to data from outside of Facebook services by Facebook. As a result of these findings, the decision prohibited Facebook from making the private use of Facebook social network conditional on Facebook being able to combine information saved on Facebook users' account with information collected on third-party websites or mobile apps without user consent. ${ }^{117}$

\section{Exclusionary abuse of market power}

According to the Bundeskartellamt, illegal data aggregation also formed a barrier to entry for Facebook's potential competitors in the social networking market. ${ }^{118}$ The aggregation (inter alia the collection, combination and analysis) of data is considered, in this decision, to be an essential basis for the emergence and success of a social network business model. ${ }^{119}$ This was envisaged by the German legislator through the introduction of the data access criterion under $\S 18$ paragraph 3a no. 4 GWB. ${ }^{120}$ As has been already mentioned, access to data helps to establish very detailed knowledge about the user. This knowledge enables, in turn, successful targeted advertising which is demanded by the advertisers who fund the social network. ${ }^{121}$

The Bundeskartellamt found that Facebook gained a competitive advantage over its competitors by the aforementioned inappropriate data aggregation from different sources and their combination with Facebook accounts. ${ }^{122}$ The unlawfully collected and combined data allowed Facebook to optimize its services as well as to attract more users and advertisers to its products. ${ }^{123}$ Such data was, however, not available for these competitors who have lawfully handled the processing of personal data in the past and nowadays find themselves at a competitive disadvantage compared to Facebook. ${ }^{124}$

117 Decision, p. 2.

118 Decision, p. 279, point 888.

119 Ibidem.

120 Ibidem.

121 Ibidem.

122 Decision, p. 280, point 888.

123 Decision, p. 279, points 886-887.

124 Decision, p. 280, point 888. 
The already existing advantage of Facebook, due to its access to a great amount of competitively-relevant data, was further expanded by inappropriate and thus illegal combination of data retrieved from other sources with Facebook accounts. ${ }^{125}$ This phenomenon increased the existing market entry barrier which is strengthened through the direct network effects. ${ }^{126}$ In this context, Facebook's abusive terms and conditions were of market power relevance. ${ }^{127}$ Facebook's anticompetitive access to data has therefore secured its market power towards end customers and competitors in the advertising market as well as raised barriers to entry for potential competitors on the social network market.

\section{Prohibition}

All of the above led the Bundeskartellamt to issue Decision no. B6-22/16, which prohibited Facebook, as a dominant company on the national market of social networks for private users, from making use of Facebook social network by private users residing in Germany, conditional on Facebook being able to combine information saved on Facebook users' account with user and device-related data collected through its corporate services as well as through Facebook Business Tools without user consent. ${ }^{128}$ The Bundeskartellamt has also prohibited the data processing policy expressly stated in Facebook's terms of service and detailed in the data and cookie policies, which Facebook imposes on its users and ordered the termination of this conduct. ${ }^{129}$

\section{Bundeskartellamt decision B6-22/16 - analysis}

The above presented Buneskartellamt decision has been broadly commented on. Some pointed out the problematic issues pertaining to the definition of the relevant market ${ }^{130}$ (Małobędzka-Szwast, 2018, p. 145-146 and Cunnane, 2019), some criticized the flexible approach to market

125 Decision, p. 279-280, point 888.

126 Ibidem.

127 Decision, p. 280, point 888.

128 Decision, p. 288, point 916.

129 Ibidem.

130 The problematic issues included: the disregard of the Bundeskartellamt of the second side of this multi-sided market, meaning the advertising side and focusing only on the user-side; the limitation of the geographical market only to the German market instead of global one. (Małobędzka-Szwast, 2018). 
definition based on functional similarities and differences (Lamadrid, Ibanez Colomo, 2019), others appraised the functional interchangeability-test carried out by this Office (Newman, 2019). Yet some found that the abusiveness test carried out by the Bundeskartellamt is valid (Volmar and Helmdach, 2018) while others would probably find this test to be unnecessarily intruding into the competences of data protection authorities and blurring the delineation between data protection rules and competition rules (Lamadrid, 2014).

As described above, the Bundeskartellamt identified two anticompetitive practices of Facebook. First, the exploitative one, where users were forced to accept Facebook's abusive terms and conditions. Second, the exclusionary one, where the abusive business terms impeded Facebook's competitors from entering or strengthening their position on social networks and advertising markets. While the first practice raised a lot of concerns, the second, while still requiring attention, seems to be less controversial.

\section{Data aggregation as a barrier to market entry}

The Bundeskartellamt recognized in its decision that Facebook's vast access to competitively relevant-data, together with the direct and indirect network effects, constitutes a barrier to entry for newcomers to the social network market. This finding follows from the acceptance of the fact that data are of a competitive significance and that having exclusive access to a certain type or scope of illegally acquired data can constitute a breach of competition law. Moreover, if data is considered an important input of production for the services provided on the online platform, and a specific and competitively-relevant data, necessary for new entrants to compete with the dominant incumbent, is not accessible, the databases held by an incumbent may constitute an entry barrier (Graef, 2015, pp. 488-489).

It is worth noting that access to data can be limited in a variety of ways. Databases and their content are protected by the law. While the structure of a database enjoys copyright protection, its content, for which obtaining, verification or presentation a substantial investment has been made on the side of the database producer, is protected sui generis (Graef, 2015, pp. 480-482). The content of the database that has been created through user activity and collected by a business entity, such as information on suppliers and customers (users), can be protected as trade secrets (Graef, 2015, p. 482).

The Office, after finding that Facebook's vast access to competitively relevant-data, together with the direct and indirect network effects, constitutes a barrier to entry for newcomers to the social network market who have a limited access to these data, did not impose a duty on Facebook 
to share that data with its competitors. This could have been possible if the Bundeskartellamt had imposed a duty to deal through, for example, forced licensing agreements of databases. It seems that the Bundeskartellamt did not want to further scrutinize the possibility of market foreclosure, but focused only on the limited extent of illegal data processing.

However, also a refusal to supply user data to competitors, when the data controller is a dominant entity on the market, could constitute another form of anticompetitive behaviour. When certain data are to be considered an 'essential facility', the competition authority might impose upon a dominant player the duty to share data ${ }^{131}$ (Gurkaynak, Guner and Yasar, 2015, p. 163). For a dataset to be an essential facility, there has to be "no actual or potential substitute on which competitors in the downstream market could rely so as to counter - at least in the long-term - the negative consequences of the refusal'. ${ }^{132}$ In order to identify data as essential there has to be no possibility to duplicate them in the foreseeable future. The possibility of duplication means that 'the creation of an alternative source of efficient supply that is capable of allowing competitors to exert a competitive constraint on the dominant undertaking in the downstream market' is possible. ${ }^{133}$

Indeed, the Bundeskartellamt identified at one point that the data to which Facebook has access are essential, as competitors cannot duplicate them, especially when they are smaller and have only limited financial or business possibilities to aggregate data from various relevant sources, but refused to impose any sanctions or orders on this ground. ${ }^{134}$ The characteristics of Facebook accurate and highly-detailed data show that the competitors' sources are not comparable ${ }^{135}$ and that Facebook has a unique database of advertisingrelevant data. ${ }^{136}$ Even the Google's database, which is comparable to the data aggregated by Facebook, in the view of its amount and detail, did not achieve market success on the market for social networks for private users, because

131 As an example of competition authority's decision where the sharing of dataset was imposed upon the incumbent please see: Autorite de la concurrence. Décision n ${ }^{\circ} 14-\mathrm{MC}-02 \mathrm{du}$ 9 septembre 2014 relative à une demande de mesures conservatoires présentée par la société Direct Energie dans les secteurs du gaz et de l'électricité (2014).

132 Communication from the Commission - Guidance on the Commission's enforcement priorities in applying Article 82 of the EC Treaty to abusive exclusionary conduct by dominant undertakings, OJ C 45, 24.2.2009, p. 7-20, para. 83 (hereinafter: Guidance on Abusive Exclusionary Conduct).

133 Ibidem.

134 Decision, p. 160, point 498.

135 Decision, p. 160, point 498. The investigation showed that Facebook's competitors, except Google, did not collect data from their corporate services, nor have they installed social plugins such as Like or Share or Log-in button (Decision, p. 160, point 498).

136 Decision, p. 160, point 499. 
of strong direct network effects that are associated with Facebook's social network service. ${ }^{137}$

All of the above indicates that Facebook's data might be regarded as an essential facility for its competitors on several markets. ${ }^{138}$ However, the Bundeskartellamt refused to analyze further the matter and did not issue an order for Facebook to share its data with competitors. The Office's limited analysis is probably based on the fact that the scope of the proceedings did not cover Facebook's refusal to share data. Moreover, Facebook's aggregated data might not have fulfilled all the requirements in order to be covered by the essential facility doctrine, ${ }^{139}$ or the sharing of personal data could not be envisaged by the Office as it would violate data protection provisions, which allow for personal data transfer only under certain circumstances. ${ }^{140}$

137 Decision, p. 160-161, point 499.

138 As the Autorité de la concurrence and the Bundeskartellamt have indicated in their joint report from 2016 'conducts depriving some competitors from access to data could also weaken competition and even lead to exclusion of competitors in different situations', one of this situations could occur when data is an essential facility for an undertaking asking for access to carry its economic activity (Autorité de la concurrence and Bundeskartellamt, 2016, p. 17.).

139 The requirements for a database as an intellectual property right or a form of know-how to be shared have been enumerated in the CJ judgment of 29 April 2004 in Case C-418/01 IMS Health, ECLI:EU:C:2004:257, paras. 28, 52). For a database to be considered an essential facility, to which the access should be provided, it must be determined that: there are no products or services which constitute alternative solutions, even if they are less advantageous; technical, legal or economic obstacles exist capable of making it impossible or at least unreasonably difficult for any undertaking seeking to operate in the market to create alternative products or services; the undertaking which requested access intends to offer new products or services not offered by the owner of the essential facility and for which there is a potential consumer demand; the refusal is not justified by objective considerations; the refusal is such as to eliminate all competition on that market.

140 An example of domestic case-law where blocking of forced personal data sharing from the dominant entity to its competitors on a downstream-market on a basis of the data protection provisions incorporated in the Finnish Act on the Protection of Privacy in Electronic Communications (OJ 516/2004) took place, is the Judgment of the Finnish Market Court of 6 April 2009 in combined cases Dnro 281/05/KR and Dnro 293/05/KR. The Market Court found Suomen Numeropalvelu Oy - Finlands Nummertjänst Ab (SNOY) guilty of abuse of dominance by refusing to submit telephone subscriber information for the electronic telephone catalogue provided by Eniro Oy, but due to the amendments to the Finnish Act on the Protection of Privacy in Electronic Communications, which required the entities carrying data processing activities to inform the telephone number holders about the purpose of their personal data processing as well as to inform them about the right to object the publication of their data in electronic telephone catalogue, SNOY was no longer obliged to unconditionally share data with its competitor (see judgment of the Finnish Market Court of 6 April.2009 in combined cases Dnro 281/05/KR and Dnro 293/05/KR, para. 282). 


\section{GDPR violation as an antitrust violation}

\subsection{German perspective}

The most debated issue concerning the decision pertains to the fact that the Bundeskartellamt interprets the rulings of the German Federal Court of Justice in VBL-Gegenwert I and Pechstein cases as implying that a violation of any consumer protection law, data protection law inclusive, by a dominant entity is able to constitute a harm under competition law (Manne, 2019) and that data protection law is a sort of consumer protection law (Volmar and Helmdach, 2018, p. 198). What has been criticized is that the Bundeskartellamt made a referral to the above-mentioned jurisprudence, which in fact involves very different factual backgrounds (Heinz, 2018). While Pechstein is about 'agreement imposed by monopolist International Skating Union on athletes for competing in the world championships, so essentially concerning the basic right to carry out their profession' (Heinz, 2018), and VBL-Gegenwert I is about 'the provision of retirement benefits and a condition inappropriately impeding customers from exiting a long-term agreement with the dominant supplier' (Heinz, 2018), S. Heinz finds that the Facebook case is about 'access to social network for leisure purposes' (Heinz, 2018), which needed to be taken into account when balancing the interests but it was not. However, both judgments refer back to the possibility of the competition authority to assess the abusiveness of terms of contract on the basis of the verification whether such conditions do not infringe the legal provisions from other branches of law, and are balanced in the view to fundamental rights, which is what the Bundeskartellamt had the right to verify.

The Bundeskartellamt, by taking the view that an application of Article 19 GBW is possible whenever the party is in an unbalanced negotiating position against contract terms which violate constitutional rights (Pechstein) or civil provisions (VBL-Gegenwert I), and by applying this understanding also to the violation of data protection law, quite importantly broadened its competences in the assessment of the abusiveness of these terms. The proportionality test carried by the Bundeskartellamt shows its reliance on fundamental rights, but this seems to be only possible due to the interpretation presented in the German jurisprudence. If such a balancing exercise would have to be carried out in accordance with EU jurisprudence, then the interests of the parties could have been determined differently.

The balancing of interests might have to be carried out on the user interest to use the social network free of charge and Facebook's objective to provide such a network free of charge. The development and maintenance of this social network service requires significant innovation and substantial 
investment from Facebook's side, and in return it obliges users to provide it with a broad scope of user data (Linklaters, 2019). Recent studies have shown that users are not willing to pay for services which offer them greater privacy (this phenomenon is called a 'privacy paradox') ${ }^{141}$. Thus, it seems they might not feel that Facebook's vast data collecting practices are improper. What they seem to worry about is their ability to access the social network for free. The Bundeskartellamt did not, however, assess the possibility that indeed users are willing to agree to Facebook's terms and conditions as they would find the aggregation of their data by Facebook as a fair, hence proportionate, price for a free service (Linklaters, 2019). The Bundeskartellamt, by sticking to German jurisprudence, has found itself competent to assess if Facebook's terms and conditions violate the GDPR, and whether this violation is able to constitute a 'harm' under competition law. The Bundeskartellamt clearly identified that a violation of the GDPR provisions constitutes a harm under competition law.

\subsection{Commission and CJEU perspective}

However, the position of the Commission and the CJEU on the possibility of intertwining data protection principles and competition rules differs from the one proposed by the Bundeskartellamt. CJEU position presented in the AsnefEquifax ${ }^{142}$ judgment, together with Commission's views presented in merger cases (TomTom/TeleAtlas, ${ }^{143}$ Google/Doubleclik, ${ }^{144}$ Facebook/WhatsApp ${ }^{145}$ LinkedIn/Microsoft, ${ }^{146}$ Google/Sanofi/DMI JV ${ }^{147}$ ), showed that neither the CJEU nor the Commission is willing to include data protection parameters in its analysis even if it has been observed in LinkedIn/Microsoft merger case that data may have a potential economic relevance for entities' market position. ${ }^{148}$ Some scholars, have however argued that since there has been 'not a single abuse of dominance case that expressis verbis disregards the relevance of data

141 '[U]sers claim to be very concerned about their privacy but do very little to protect their personal data (...). Although users are aware of privacy risks on the internet, they tend to share private information in exchange for retail value and personalized services'. This holds true also for the users of social networks. (See: Barth, Jong (2017), p. 2).

142 CJ judgement of 23 November 2006, Case C-238/05 Asnef-Equifax et al v. Asociaci ón de Usuarios de Servicios Bancarios, ECLI:EU:C:2006:734, para. 63 (' any possible issues relating to the sensitivity of personal data are not, as such, a matter for competition law, they may be resolved on the basis of the relevant provisions governing data protection').

143 European Commission, Case No. COMP/M.4854 - TomTom/Tele Atlas.

144 European Commission, Case No. COMP/M.4731 - Google/DoubleClick.

145 European Commission, Case No .COMP/M.7217 - Facebook/Whatsapp.

146 European Commission, Case M.8124 - Microsoft/LinkedIn.

147 European Commission, Case M.7813 - Sanofi/ Google / DMI JV.

148 European Commission, Case M.8124 - Microsoft/LinkedIn, para. 179. 
protection laws' there is no rule that compels the competition authorities to apply this 'separation dogma' to abuse of dominance cases (Volmar, Helmdach, 2018, p. 209).

For example, it is possible to derive from the Astra Zeneca ${ }^{149}$ case that the abuse of a dominant position could arise if the incumbent provided misleading information with the lack of transparency (Schneider, 2018, p. 222-223). Therefore, an abuse 'can result from company's non-transparent data collection standards' (Schneider, 2018, p. 222-223). Moreover, looking at the BRT II ${ }^{150}$ case, if similar to the Bundeskartellamt's Facebook proceedings would have been carried out by the Commission, it would not have to refer to data protection law in order to find an abuse, but it could base its finding solely on the inappropriateness of the terms (Volmar and Heldmach, 2018, p. 203). The violation of data protection law only strengthens the abuse theory, which simply requires that the clause of the agreement is not strictly necessary for the provision of a particular service, thus not necessary to achieve the object of the contract. If collecting data about a user's online behaviour outside of Facebook is not necessary for him to use Facebook, then the data processing provisions embedded into the contract may be unnecessary from the perspective of the proportionality test (Volmar and Helmdach, 2018, p. 202). If data processing lacks necessity, it could therefore 'fail both the GDPR and the proportionality test' (Volmar and Helmdach, 2018, p. 203), since the necessity test of terms and conditions relating to the processing of personal data on social network markets can be carried out only through the analysis of GDPR provisions, competition authorities would therefore seem to be, on the basis of this particular ruling, authorized to establish an abusive nature of these terms.

As a result of the BRT II case, the ECJ determined that if abusive practices are exposed, it is possible to decide on 'consequences with regard to the validity and effect of the contracts in dispute or certain of their provisions'. ${ }^{151}$ The Bundeskartellamt did not, however, decide on the invalidity of the contractual clauses pertaining to the data protection, and effects of these contracts, but imposed a duty to change the data processing behaviour of Facebook. This decision should therefore be seen as an interference with the competences of data protection authorities (supervisory authorities).

149 CJ judgment of 6 December 20120, Case C-457/10 Astra Zeneca v Comission, ECLI:EU:C:2012:770, para. 93.

150 ECJ judgment of 27 March 1974, Case 127/73 Belgische Radio en Televisie and société belge des auteurs, compositeurs et éditeurs v SV SABAM and NV Fonior, ECLI:EU:C:1974:25 (hereinafter: BRT-II).

151 Case 127/73 BRT-II, para. 14. 


\subsection{The delineation of competence between the competition and data protection authorities}

EU Charter of Fundamental Rights under its Article 8 establishes the following:

1. Everyone has the right to the protection of personal data concerning him or her.

2. Such data must be processed fairly for specified purposes and on the basis of the consent of the person concerned or some other legitimate basis laid down by law. Everyone has the right of access to data which has been collected concerning him or her, and the right to have it rectified.

3. Compliance with these rules shall be subject to control by an independent authority. ${ }^{152}$

On the basis of Article 55 GDPR, 153 it is the data protection authority (called supervisory authority), not the competition authority, that is competent to verify and identify infringements of data protection law. One of the primary tasks of the supervisory authorities is to monitor and enforce the application of the GDPR, as well as to fulfil any other tasks related to the protection of personal data, on its territory. ${ }^{154}$ The inclusion of data protection issues into the competitive analysis seems to lead to an unnecessary blurring of these two distinctive branches of law, and to the interference of the competences of the competition authority with the competences of the data protection authority (Lamadrid, 2014).

It is, however, true that the market players in the digital economy propose 'zero-price' services where the user does not have to pay for the services with their money but with their data and that this data later translates, through advertisers, into monetary gain for those who offer them. Consequently, it can be established that data, particularly personal data, can be a source of market power and serve as a basis for the obtaining of a dominant position in data-driven markets, such as the social network market.

The Bundeskartellamt states that since access to data is essential for the establishing of the market position of a company, the way it gathers and further uses that data can be scrutinized by the competition authority. ${ }^{155}$ Some

152 Charter of Fundamental Rights of the European Union, OJ C 326, 26.10.2012, pp. 391-407.

153 'Each supervisory authority shall be competent for the performance of the tasks assigned to and the exercise of the powers conferred on it in accordance with this Regulation on the territory of its own Member State' (Article 55 GDPR).

154 See Article 57(1)(a),(v) GDPR.

155 This conclusion repeats findings of the Bundeskartellamt and the Autorite de la concurrence joint report were it was established that the way personal data is processed 'could be considered from a competition standpoint whenever these policies are liable to affect competition, 
displeased with the approach of the Bundeskartellamt argue that 'all sort of features are essential for the market position of economic entities: product quality, prize, IP, consumer loyalty, branding, reputation' (Manne, 2019), but the Bundeskartellamt failed to assess all of these qualities. The Bundeskartellamt did, however, answer the question why other competitive features of Facebook's business model have not been taken into consideration, and why the way in which access to data is generated is so fundamentally different from other competitive features of this particular market. First, the recent amendment of the GWB has reflected the importance of data for markets which have the characteristics of a network. The relevant market is a data-driven one, meaning that without personal data of its users it would not be able to function as a zero-prized market, and this particular market's feature is different from any other relevant market where personal data are not so essential. Thus, in the opinion of the Bundeskartellamt, the data protection parameters, as being inherent to the market position on data-driven markets, have to be assessed. Moreover, the data protection provisions are to be understood as sort of consumer protection provisions that are also relevant for the competition protection authorities, which have to keep an eye on the balance of power between negotiating parities to a contract. ${ }^{156}$

This link of personal data collection with the possible creation of a dominant position shows a certain interaction between data protection and competition rules. It should, however, remain clear that data protection authorities have their own distinct competences in the assessment of the infringements of GDPR provisions, and that competition authorities are competent to assess the abusive nature of the terms and conditions imposed by dominant entities.

Each supervisory authority has been given a power to 'order the controller or processor to bring processing operations into compliance with the provisions of this Regulation, where appropriate, in a specified manner and within a specified period'. ${ }^{157}$ This power has been, however, in the Bundeskartellamt decision, implemented not by the supervisory authority but by the competition authority. It can be therefore observed that ' $[\mathrm{b}] \mathrm{y}$ doing this FCO [Bundeskartellamt] reaches into the area of data protection and claims that the data protection authorities do not have exclusive competence in this area' (Linklaters, 2019).

It seems that on digital markets the way in which personal data are processed might be one of the elements of the analysis of the fairness of terms under national and EU competition law, however it cannot constitute a core

notably when they are implemented by a dominant undertaking for which data serves as a main input of its products or services' (Bundeskartellamt, Autorite de la Concurrence , 2016, p. 23).

156 Decision, p. 283, para. 901.

157 Article 58 (2)(d) GDPR. 
of the analysis. Looking at the competence of the supervisory authorities, it can be argued that competition authorities in the EU should not determine by themselves whether the terms of the contract relating to data processing constitute an infringement of the GDPR. A competition authority, in its analysis of the abusiveness of business terms, should rely on the supervisory authority's decision made prior to the competition authority's decision, where the infringing nature of such a processing under the GDPR would have been recognized. Otherwise, unless such a decision by the supervisory authority is issued, the competition authority could only rely on the proportionality test in order to asses fairness of these terms, which might be insufficient without the legal analysis of the compliance with the GDPR.

Therefore, the assignment of the competences of the data protection supervisory body by the Bundeskartellamt, which is a competition authority, in assessing the relevance of Facebook's terms and conditions with the GDPR seems to be the most problematic issue, as it goes against the Commission view that any privacy-related issues flowing from the increased data concentration fall within the scope of EU data protection law and not within EU competition rules. Facebook's appeal to the Regional Higher Court (Oberlandesgericht) in Düsseldorf, will provide an answer as to whether the Bundeskartellamt is a competent body to carry out such an analysis under German law. The outcome of the court proceedings will also determine the future of Bundeskartellamt's policy regarding proceedings and its possibility to assess other abuse of dominance cases that relate to the intertwining between data protection and competition law. However, the answer to the question whether and if so, to what extent, the Commission or other EU competition authorities are competent to assess the validity of contractual terms regulating the data processing policies with the GDPR, still remains open.

\section{Conclusion}

The Bundeskartellemt's decision in the Facebook case reflects the dangers created by illegal data-aggregation practices to both competitors and consumers. This decision also reflects the importance of non-financial parameters, such as privacy and data protection on 'free markets' and acknowledge the opinion of the European Data Protection Supervisor Giovanni Buttarelli that there might exist a form of abuse of dominance where the dominant entity would abusively use "non-negotiable "privacy policies"' (Buratelli, 2015, p. 5).

The latest amendment to GWB may support the Bundeskartellamt's view that personal data serve as a relevant competitive parameter. This amendment 
includes access to data into the assessment of market dominance on relevant markets with the characteristics of a network (a multi-sided market), but does not relate to the ability of the German competition authority to assess the abusiveness of data protection policies embedded into a network's terms and conditions. This ability for the German competition authority derives from the jurisprudence of the Federal Court, which allows the scrutiny of business terms from the civil law and fundamental rights' perspectives. This could also be possible for the Commission which might rely on CJEU jurisprudence regarding the balance of interests test. However, it is not yet determined whether the performance of such a test by competition authorities would not impede the competences of data protection supervisory authorities.

The possibility to acknowledge the abusiveness of contractual terms regarding the processing of personal data by the competition authority stays problematic. One of the possibilities to avoid conflicts of jurisdiction is that only after a decision about the infringing character of these particular terms in the view of the GDPR would be issued by the competent supervisory authority, the competition authority could then rely on these findings in order to take measures that would safeguard consumer interests and sanction incumbents for their abusive behaviour from the anticompetitive perspective, if a harm under competition law could be established (of course the competition authority would have to respect the ne bis in idem rule).

The Bundeskartellamt's position presented in the Facebook proceeding seems to indicate that monitoring of data processing activities of dominant companies cannot be fulfilled solely by supervisory authorities and for this purpose, the intervention of the competition authority, whenever the entity enjoys a dominant position, is possible.

\section{Literature}

Article 29 Working Party (2017). Guidelines on consent under Regulation 2016/679 (WP259 rev.01) Adopted on 28 November 2017 As last Revised and Adopted on 10 April 2018. Retrieved from: https://ec.europa.eu/newsroom/article29/document. cfm?action $=$ display \&doc_id $=51030(31.07 .2019)$.

Autorité de la concurrence and Bundeskartellamt (2016). Competition Law and Data Report. Retrieved from: http://www.autoritedelaconcurrence.fr/doc/reportcompetitionlawanddatafinal.pdf (31.07.2019).

Barth, S., Jong, M.D.T. (2017).The privacy paradox - Investigating discrepancies between expressed privacy concerns and actual online behavior - A systematic literature review. Telematics and Informatics, Vol. 34/7, 1038-1058. https://doi.org/10.1016/j. tele.2017.04.013. 
Buttarelli, G. (2015). Privacy and Competition in the Digital Economy speaking points at the European Parliament's Privacy Platform, 21 January 2015. Retreived from: https://edps. europa.eu/sites/edp/files/publication/15-01-21_speech_gb_en.pdf (20.06.2019).

Bundeskartellamt. (2018). Arbeitspapier Marktmacht von Platformen und Netzwerken. Retrieved from https://www.bundeskartellamt.de/SharedDocs/Publikation/DE/Berichte/ Think-Tank-Bericht.pdf?_blob=publicationFile\&v=2 (15.06.2019).

Bundeskartellamt. (2019). Case summary, Facebook, Exploitative business terms pursuant to Section 19(1) GWB for inadequate data processing. Publication place: Bundeskartellamt. Retrieved from: https:/www.bundeskartellamt.de/SharedDocs/ Entscheidung/EN/Fallberichte/Missbrauchsaufsicht/2019/B6-22-16.html?nn=3591568 (17.06.2019).

Bundeskartellamt. (2019a). Bundeskartellamt prohibits Facebook from combining user data from different sources, Background information on the Bundeskartellamt's Facebook proceeding, Retrieved from : https://www.bundeskartellamt.de/SharedDocs/ Publikation/EN/Pressemitteilungen/2019/07_02_2019_Facebook_FAQs.pdf? blob $=$ publicationFile \&v $=6$ FAQ (17.06.2019).

Cunnane, Y. (2019). Why We Disagree With the Bundeskartellamt. Retrieved from: https://newsroom.fb.com/news/2019/02/bundeskartellamt-order/ (31.07.2019).

Evans, D. (2016). Multisided Platforms, Dynamic Competition, and the Assessment of Market Power for Internet-Based Firms. CoaseSandor Working Paper Series in Law and Economics, No. 753 (2016).

Evans, D., Schmalensee, R. (2007). The Industrial Organization of Markets with TwoSided Platforms, CPI Journal, Competition Policy International, vol. 3, 6-11, http://dx.doi. org/10.3386/w11603.

Graef, I. (2015). Market Definition and Market Power in Data: The Case of Online Platforms, World Competition: Law and Economics Review, vol. 38/4, 473-506, http:// dx.doi.org/10.2139/ssrn.2657732.

Grunes, A.P., Stucke, M.E. (2015). No Mistake About It: The Important Role of Antitrust in the Era of Big Data, Antitrust Source, vol. 14/4, 1-14.

Gurkaynak, G., Güner Dönmez, A., and Yasar, A.G. (2015). Competition Law and Personal Data Crossing in Digital Markets. Ian S. Forrester, A Scott without Borders, Liber Amicorum - Volume II, Concurrences Review, 153-172, https://dx.doi.org/10.2139/ ssrn.3149530.

Heinz, S. (2018). Bundeskartellamt sends preliminary assessment to Facebook. Retrieved from: http:/competitionlawblog.kluwercompetitionlaw.com/2018/01/09/ bundeskartellamt-sends-preliminary-assessment-facebook/ (31.07.2019).

Lamadrid, A. (2014). On Privacy, Big Data and Competition Law (2/2) On the nature, goals, means and limitations of competition law. Retrieved from: https://chillingcompetition. com/2014/06/06/on-privacy-big-data-and-competition-law-22-on-the-nature-goalsmeans-and-limitations-of-competition-law/ (31.07.2018).

Lamadrid, A., Ibáñez Colomo, P. (2019). The Bundeskartellamt's Facebook DecisionWhat's not to like? Well.... Retrieved from: https://chillingcompetition.com/2019/02/27/ the-bundeskartellamts-facebook-decision-whats-not-to-like-well/ (31.07.2019).

Linklaters. (2019). Facebook - Bundeskartellamt's landmark decision blurs the line between data protection and competition law. Retrieved from: https://www.linklaters. com/pl-pl/insights/publications/2019/april/facebook-bundeskartellamt-s-landmarkdecision (01.08.2019). 
Małobędzka-Szwast, I. (2018). Naruszenie prawa ochrony danych osobowych jako nadużycie pozycji dominującej? Postępowanie Bundeskartellamt przeciwko Facebookowi. Internetowy Kwartalnik Antymonopolowy i Regulacyjny, vol. 8/7, 139-153, http://dx.doi.org/ 10.7172/2299-5749.IKAR.8.7.10. Retrieved from: https://ikar.wz.uw.edu.pl/numery/ 55/139.pdf.

Manne, G., Doing double damage: The German competition authority's Facebook decision manages to undermine both antitrust and data protection law, https://truthonthemarket. com/2019/02/08/doing-double-damage-bundeskartellamt-facebook/ (31.07.2019).

Mordall, J. (2018). Big Data and Merger Control in the EU. Journal of European Competition Law \& Practice, vol. 9/9, 569-578, https://dx.doi.org/10.1093/jeclap/lpy062.

Newman, J. (2019). The Bundeskartellamt's Facebook Decision: Good, Bad and Ugly. Retrieved from: https://leconcurrentialiste.com/2019/02/11/bundeskartellamt-facebook/ (31.07.2019).

Schneider, G. (2018). Testing Art. 102 TFEU in the Digital Marketplce: Insights from the Bundeskartellamt's investigation against Facebook. Journal of European Competition Law \& Practice, vol. 9/4, 213-225, https://dx.doi.org/10.1093/jeclap/lpy016.

Volmar, M.N., Helmdach K.O. (2018). Protecting consumers and their data through competition law? Rethinking abuse of dominance in light of the Federal Cartel Office's Facebook investigation, European Competition Journal, 14/2-3, 195-215, http://dx.doi. org/10.1080/17441056.2018.1538033.

Zanfir-Fortuna, G., Ianc, S. (2018). Data Protection and Competition Law: The Dawn of 'Uberprotection' (August 30, 2018). Research Handbook on Privacy and Data Protection Law: Values, Norms and Global Politics, Gloria González Fuster, Rosamunde van Brakel and Paul De Hert (eds.), 2019 (Forthcoming), http://dx.doi.org/10.2139/ssrn.3290824. 